\title{
Effect of Phase Composition of Calcium Phosphate (CaP) on Bioactivity of Osteon-like Composite Scaffolds
}

\author{
CHEN Xue-Ning ${ }^{1}$, FAN Hong-Song ${ }^{1}$, WANG Hong-Jun ${ }^{2}$
}

(1. National Engineering Research Center for Biomaterials, Sichuan University, Chengdu 610064, China; 2. Department of Chemistry, Chemical Biology and Biomedical Engineering, Stevens Institute of Technology, Hoboken, NJ 07030 USA)

\begin{abstract}
From compositional perspective, natural bone is a kind of inorganic and organic composite material; while from structural perspective, the basic structural unit of cortical bone is vascularized osteon. In this study, based on the biomimetic principle, a tissue-engineered construct was created to stimulate the basic building block of cortical bone-osteon with complex structure. To achieve this goal, a bi-layered polycaprolactone (PCL)/CaP composite scaffold was produced via a novel two-step fabrication process in the combination of electrospinning and twin screw extrusion. Its inner hollow tube was made of electrospun nanofibers, allowing the formation of a confluent layer of endothelial cells (MS-1) to resemble the Haversian canal, and its outer layer consisted of spiral PCL/CaP microfilament with high porosity, facilitating the proliferation and differentiation of pre-osteoblasts (MC3T3-E1) to form bone-like tissues. To explore the effect of material composition on scaffold bioactivity, three composite scaffolds with different outer layers were fabricated, including PCL, PCL/biphasic calcium phosphate (BCP) and PCL/ $\beta$-tricaclium phosphate ( $\beta$-TCP). And then the influences of scaffold composition on the behaviors of pre-osteoblasts were further investigated. Compared to PCL and PCL/ $\beta$-TCP, significantly more cell growth and higher calcium deposition are found on PCL/BCP scaffolds, precisely controlling the spatial distribution of different cells. Taken together, this bi-layered PCL/BCP scaffold partially mimics the complex structure of osteon, showing a promising potential in the orthopedic application.
\end{abstract}

Key words: calcium phosphate; phase composition; composite; osteon; twin screw extrusion

Tissue engineering holds great promise for repairing of bone defects ${ }^{[1-2]}$. However, very limited progress has been made to engineer construct for cortical bone, due to its dense and complex structure that contributes to its role as the major load-bearing component of human body. One possible approach is to mimic the hierarchical complexity of cortical bone via engineering its basic building blocksosteons. Some groups tried to use electrospun nanofibrous rods to create osteon-like constructs, but it is difficult to recapitulate the intricate structure of natural osteon, which has a central vascularized Haversian canal surrounded by concentric osseous layers $^{[3]}$.

Literatures have demonstrated the advantages of twin screw extrusion in fabricating scaffolds for bone tissue engineering, due to its versatile ability to integrate with other processing techniques, its potential of industrial scale-up, as well as its feasibility of producing graded scaffolds with diverse porosity, components and mechanical properties ${ }^{[4-6]}$. Moreover, previous findings suggested that electropun nanofibrous tubes exhibited the promising potential for creating vascular grafts ${ }^{[7]}$.

It is well known that natural bone is a kind of inorganic and organic composite material. Due to its compositional similarity to inorganic component of natural bone, calcium phosphate $(\mathrm{CaP})$ has been widely used in orthopedic application, including hydroxyapatite (HA), biphasic calcium phosphate (BCP) and tricalcium phosphate (TCP ${ }^{[8-10]}$. Previous studies have demonstrated that the phase composition of $\mathrm{CaP}$ scaffolds greatly influence their osteoconductivity and osteoinductivity ${ }^{[11-13]}$. Considering its brittleness, it is difficult to engineer small-scale porous $\mathrm{CaP}$ scaffold with complex structure. Moreover, literatures suggest that polycaprolactone (PCL) exhibits good flexibility and biocompatibility ${ }^{[14]}$. Therefore, PCL/CaP composite may be 
considered as a desired material for engineering bone graft.

Here, to mimic the structure and functionality of osteon, a bi-layered scaffold with a nanofibrous hollow tube surrounded by spiral PCL/CaP microfilament was produced by the combination of electropinning and twin screw extrusion. The effects of $\mathrm{CaP}$ phase composition on the bioactivity of scaffolds were further investigated via cell seeding and biochemical analyses. The spatial distribution of different cell types in this bi-layered scaffold was also visualized by histological examination.

\section{Material and Methods}

\subsection{Scaffold fabrication}

Following the similar two-step fabrication process reported before (Fig. 1(a) $)^{[15]}$ : (1) firstly, nanofibrous hollow tubes were prepared via eletrospinning methods, by spinning 8\% PCL (MW 70,000, Scientific Polymer Products, Inc., USA) with viscosity of $0.05 \mathrm{~kg} /(\mathrm{m} \cdot \mathrm{s})$ at a speed of $0.6 \mathrm{~mL} / \mathrm{h}$ under $15 \mathrm{kV}$. (2) Secondly, the premade nanofibrous tubes were placed on a cylindrical mandrel with a capacity to perform both rotating and translational motion, and then PCL/BCP and PCL/TCP micro-filaments were deposited spirally around these tubes via twin screw extrusion. Pure PCL filaments were used as control. In brief, stock materials were prepared by mixing PCL/NaCl/PEG (poly-ethylene glycol) with a ratio of 9:10:4 and CaP particles ( $24 \%$ by weight) with different phase compositions, including $\beta$-TCP (Sigma, USA) and BCP. Here, BCP was composed of HA (Sigma, USA) and $\beta$-TCP with a ratio of 2 to 8 . Then, premixed stock materials were fed into a twin screw extruder $\left(\phi_{\text {barrel }}=7.5 \mathrm{~mm}\right.$, Material Processing \& Reserch, Inc., USA), heated to melt at $75^{\circ} \mathrm{C}$, and extruded with a speed of $45.83 \mu \mathrm{L} / \mathrm{min}$ to from microfilaments, which were directly deposited around the electrospun tubes. The scaffold structure was determined by the movement of mandrel or the components of stock materials. (3) Finally, these bi-layered scaffolds were soaked in $\mathrm{H}_{2} \mathrm{O}$ to achieve porous structures through removing porogens ( $\mathrm{NaCl}$ and $\mathrm{PEG})$.

\subsection{Scaffold characterization}

The gross structure of bi-layered scaffold was visualized by using a stereomicroscope (Nikon SMZ1500, Japan). The morphology of hollow tube and the pore structure of microfilament were analyzed by using a scanning electron microscope (LEO-982 FEG). The fiber diameter and pore size were measured via NIH Image J $1.44 \mathrm{p}$ analysis software.

\subsection{Seeding cells in scaffolds}

To gain even cell distribution, mouse pre-osteoblasts
(MC3T3-E1) were seeded in the outer microfilament layers of scaffolds by using a spinner flask $(100 \mathrm{~mL}$ volume, Bellco Glass Inc., USA) with $1 \times 10^{5}$ cells/scaffold at a stirring speed of $40 \mathrm{r} / \mathrm{min}$ overnight. Moreover, to mimic the Haversian canals, mouse endothelial cells (MS-1) were also seeded onto the inner surface of hollow tubes in the center of scaffolds. Then, the cell-seeded scaffolds were fixed inside a spinner flask for dynamic culture with complete $\alpha$-MEM medium supplemented with $10 \mathrm{mmol} / \mathrm{L}$ $\beta$-glycerophosphate and $80 \mu \mathrm{g} / \mathrm{mL}$ ascrobic acid.

\subsection{Evaluation of cellular growth and differ- entiation}

To examine the cell growth in scaffolds, samples were fixed with $4 \%$ formaldehyde, stained with $0.1 \%$ methylene blue dye and then visualized under a stereomicroscope. To determine the osteogenic differentiation of MC3T3-E1 cells seeded in scaffolds with different phase compositions, calcium deposition was analyzed by alizarin red staining. The quantification of staining was performed by dissolving precipitates in $10 \%$ acetic acid, and measuring the absorbance of extracts at $405 \mathrm{~nm}$, according to previous literature ${ }^{[16]}$. The calcium amounts of scaffold itself (BCP or TCP) should be subtracted from the total calcium amounts of cultured samples.

Moreover, to investigate the cell distribution in scaffolds, histological examination was performed by embedding fixed samples in glycol methacrylate (GMA), cutting into thin sections, and stained with hematoxylin and eosin (HE).

\subsection{Statistical analysis}

In this study, the results were statistically analyzed by one-way analysis of variance (ANOVA), and pairwise comparisons were performed by Turkey's post hoc test via SPSS software version 22.0 (Chicago, IL, USA). P value less than $0.05(p<0.05)$ was considered to be statistically significantly different.

\section{Results and Discussion}

\subsection{Structure of bi-layered scaffolds}

As shown in Fig. 1(b)-(e), a bi-layered PCL/BCP scaffold $(\phi \approx 1.2 \mathrm{~mm})$ was fabricated with an outer layer of spiral microfilament $(\phi \approx 250 \mu \mathrm{m})$ and an inner hollow tube. The structure of outer layer was controlled by the translational movement of mandrel, as slow movement created compact structure with the adjacent microfilaments that tightly connected to each other (Fig. 1(b)-(c)), while fast movement formed separate structure with the gaps (around $120 \mu \mathrm{m}$ ) among filaments (Fig. 1(d)-(e)). The results of cell culture found that compared to compact ones, the separate filaments provided more room for the adhesion and proliferation of MC3T3-E1 cells (Fig. 1(g)), whereas 


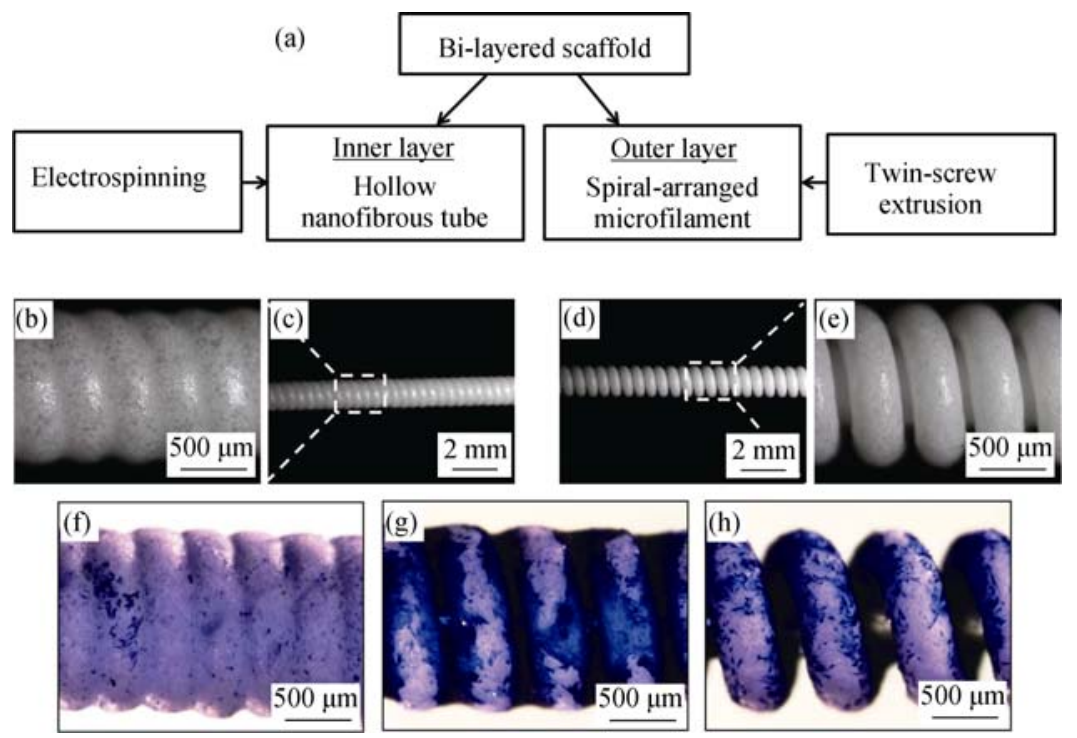

Fig. 1 (a) Two-step fabrication process to create bi-layered scaffolds with (b-c) compact and (d-e) separate microfilaments. Methylene blue staining showed cell attachment in (f) compact, $(\mathrm{g})$ separate, and $(\mathrm{h})$ inner tube-free filaments

few cells were found on the filament surface (Fig. 1(f)). Moreover, the scaffolds with only microfilament had looser structure and less cell attachment (Fig. 1(h)), suggesting that the inner hollow tubes not only helped to stabilize the outer filament layers, but also provide larger space for cell growth. Therefore, bi-layered scaffolds with both inner hollow tubes and outer separate microfilaments were chosen for further study.

SEM images of cross-section (Fig. 2(a)-(b)) further showed that the inner hollow tube $\left(\phi_{\text {inner }} \approx 500 \mu \mathrm{m}\right)$ was composed of electrospun nanofibers with about $700-800 \mathrm{~nm}$ in diameter (Fig. 2(c)), and the outer microfilament layer (Fig. 2(d)) had interconnected pore structure with both macropores $(20-30 \mu \mathrm{m})$ and micropores $(<5 \mu \mathrm{m})$ derived from the removal of porogens ( $\mathrm{NaCl}$ and $\mathrm{PEG})$.

\subsection{Surface structure of microfilaments}

SEM images found that although there was a rich pore structure inside the microfilaments (Fig. 2(d)), only small pores $(\phi<10 \mu \mathrm{m})$ were found on the filament surface (Fig. 2(e)). It might be due to the hot-melt extrusion that brought a thin PCL layer to seal the inner pores. To "open" surface pores, the percentage of porogen-PEG in the stock materials was increased from $17.39 \%$ to $24 \%$ and $29.63 \%$, but it was difficult to fabricate filaments with PEG up to $30 \%$, due to the unsuitable viscosity of melted materials. The results indicated that PEG played an important role to modulate the morphology of pores situated on the microfilament surface, as the pore sizes increased gradually following the rising of PEG amount to more than $20 \mu \mathrm{m}$. Based on the results, the formula of stock materials was adjusted as $\mathrm{PCL} / \mathrm{NaCl} / \mathrm{PEG}$ blend at a ratio of 9:10:8 to achieve a desired surface structure, which allowed the penetration of MC3T3-E1 cells into the porous microfila- ment to facilitate the formation of bone-like tissues.

\subsection{Effect of scaffold composition on cell at- tachment and growth}

Based on the fabrication process and formula optimized above, three groups of scaffolds with similar bi-layered structure but different material composition were prepared and labeled as PCL/BCP, PCL/TCP and PCL, respectively. As MC3T3-E1 cells were stained in blue color, the results of methylene blue staining found that these scaffolds allowed the similar cellular attachment at day 1 , and the cells seeded in scaffolds displayed normal fibroblast-like cell morphology (Fig. 3(a)-(c)). At day 7, the unconfluent cell layers were seen on the microfilaments of PCL and
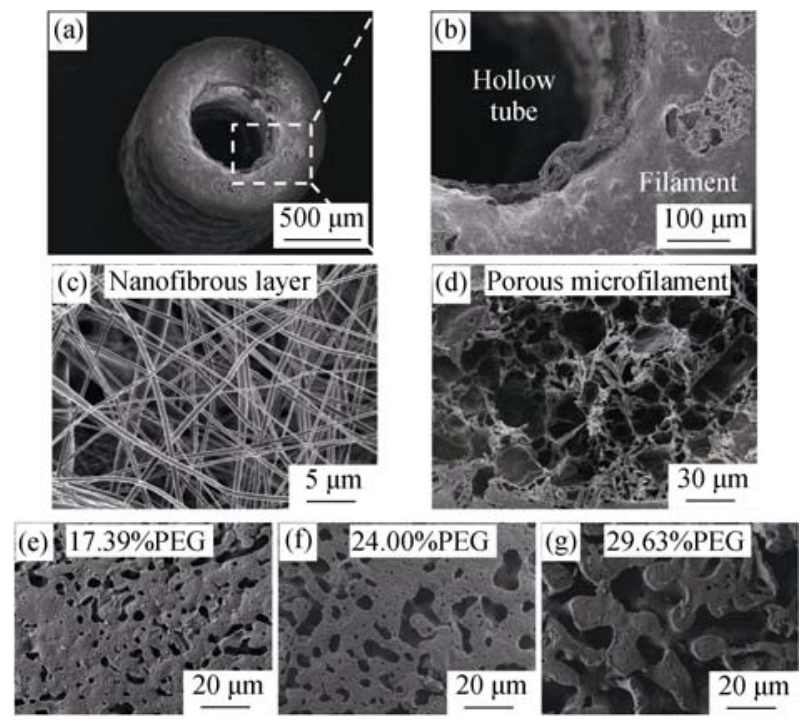

Fig. 2 SEM images of (a-b) cross-section of bi-layered scaffold, (c) nanofibrous layer of hollow tube, (d) porous structure inside the filament, and (e-g) surface structure of filament made of stock materials with different PEG amounts 


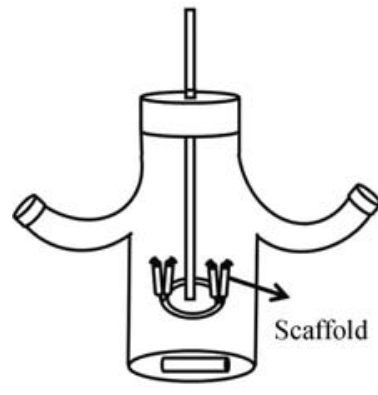

Spinner flask
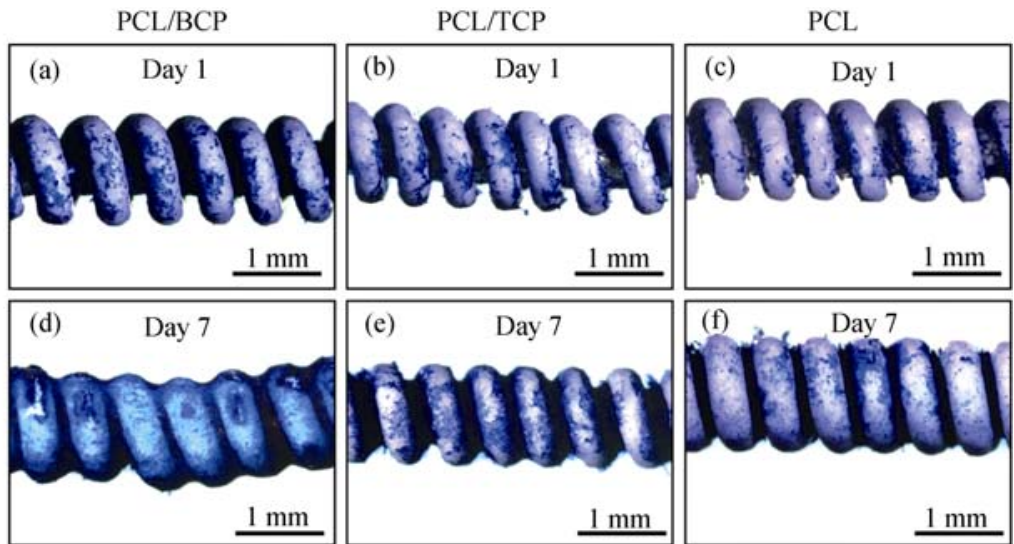

Fig. 3 The growth of MC3T3-E1 cells seeded in microfilament layers of bi-layered (a,d) PCL/BCP, (b,e) PCL/TCP and (c,f) PCL scaffolds at (a-c) day 1 and (d-f) day 7

PCL/TCP scaffolds, while cells seeded on PCL/BCP ones not only formed multiple cell layers on the filament surface, but also filled the gaps among filaments (Fig. 3(d)(f)). The results indicated that the phase composition of $\mathrm{CaP}$ in bi-layered scaffolds significantly affected the proliferation of MC3T3-E1 cells, and PCL/BCP composite scaffolds showed advantage in promoting the attachment and growth of pre-osteoblasts. It might be because that incorporating osteoconductive BCP particles into PCL filaments could improve the biocompatibility of scaffolds, which was consistent with previous findings ${ }^{[17-18]}$.

\subsection{Effect of scaffold composition on cell dif- ferentiation}

To evaluate the effect of scaffold composition on osteogenesis, calcium deposition by cells cultured on scaffolds with different composition was measured via alizarin red staining. The results (Fig. 4) found that PCL/BCP scaffolds showed the highest amount of calcium deposition, following by PCL/TCP, whereas PCL ones had the significantly lowest amount $(p<0.05)$. They indicated that CaP-incorporating PCL scaffolds could promote the osteogenic differentiation of MC3T3-E1 cells. It might be because that the composition of $\mathrm{CaP}$ particles was similar to inorganic component of natural bone to favor cell differentiation, and the dissolution of $\mathrm{CaP}$ particles facilitated the formation of biological apatite on scaffolds ${ }^{[19]}$. Moreover, phase composition of $\mathrm{CaP}$ obviously influenced the bioactivity of composite scaffolds, as PCL/BCP induced more bone formation than PCL/TCP. It was in agreement with previous findings that compared to others, $\mathrm{BCP}$ bioceramics often showed higher osteoinductive potential, for the local microenvironment produced by $\mathrm{BCP}$ degradation might be more favorable for osteogenesis ${ }^{[11-12]}$.

\subsection{Controlling cell spatial distribution}

HE staining showed that a confluent layer of endothelial cells (MS-1) formed on the inner surface of nanofibrous
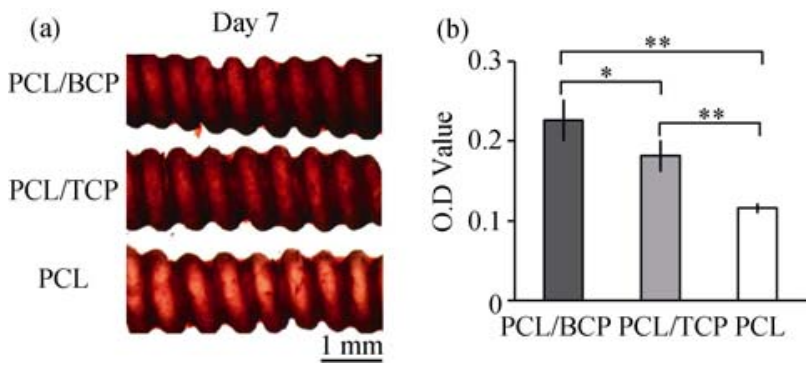

Fig. 4 Alizarin Red staining showed the osteogenic differentiation of MC3T3-E1 cells seeded in microfilament layers of bilayered scaffolds(a) and quantification of calcium deposition on scaffolds with different composition (b)

hollow tubes (Fig. 5(a)), and pre-osteoblasts (MC3T3-E1) grew in the outer microfilament layers to form cell-rich tissues (Fig. 5(b)). The results indicated that this bi-layered scaffold could precisely control the spatial distribution of two different cell types. Previous studies found the formation of tight junction among MS- 1 cells seeded in nanofibrous tube, suggesting the potential of producing functional blood vessel ${ }^{[15]}$. It is known that one of the major challenges impeding the application of tissue- engineered construct is vascularization ${ }^{[20]}$. Here, this study might represent a potential approach to fabricating vascularized engineered tissues by incorporating endothelial cell-lined nanofibrous tubes into constructs, in order to create functional vasculature to provide oxygen and nutrients. Moreover, this bi-layered scaffold with precisely controlled cell distribution could mimic the structure of osteon, as MS-1 lined hollow tube was similar to Haversian canal located in the central channel surrounding by outer bone-like tissues derived from MC3T3-E1 seeded microfilaments.

\section{Conclusion}

This study introduces a novel two-step fabrication process by combining electrospinning and twin screw 


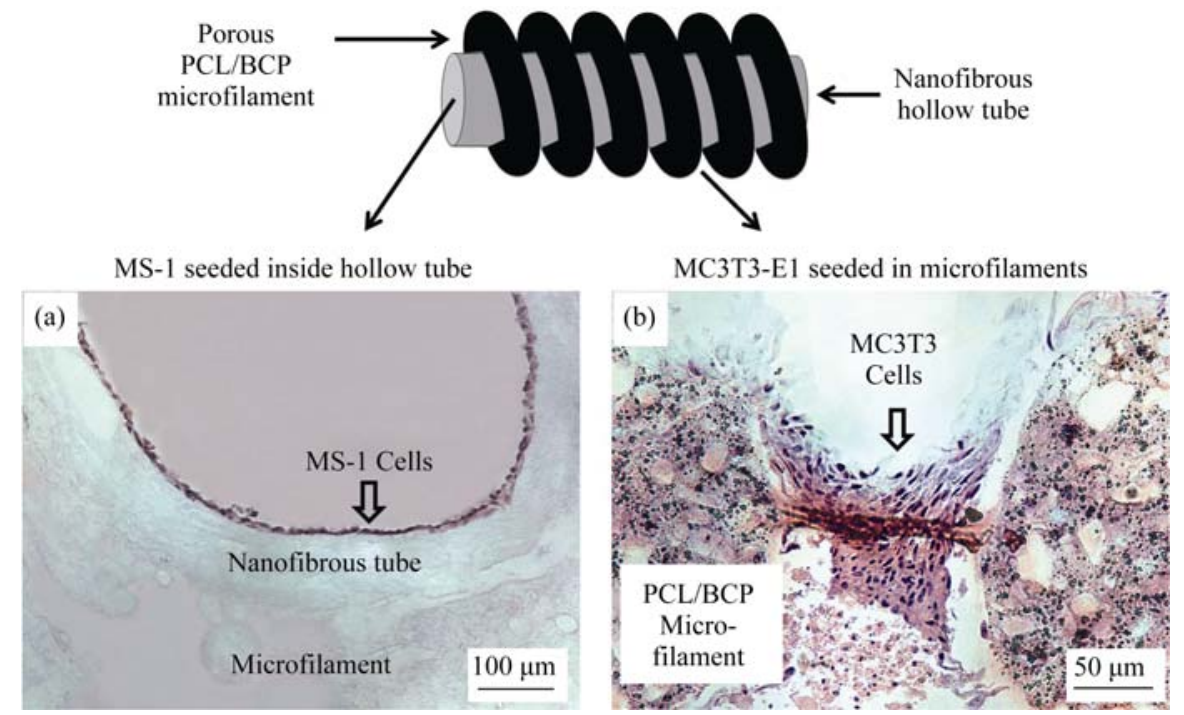

Fig. 5 Bi-layered scaffold controlled the spatial distribution of different cells

(a) A confluent layer of MS-1 cells was lined inside the nanofibrous hollow tube. (b) MC3T3-E1 cells were seeded in outer microfilament layer to form cell-rich tissue

extrusion to create a bi-layered $\mathrm{PCL} / \mathrm{CaP}$ scaffold with inner hollow tube and outer spiral microfilament, which allows precise controls of spatial distribution of different cell types, in order to mimic the complex structure and function of osteon. Moreover, phase composition of $\mathrm{CaP}$ has a certain impact on bioactivity of composite scaffolds. Compared to PCL and PCL/TCP, PCL/BCP scaffolds are more likely to promote cell growth and osteogenic differentiation. These findings provide a useful principle for designing and fabricating tissue-engineered bone constructs with structural and functional complexicity for the potential orthopedic application.

\section{Acknowledgments}

The authors would like to thank Prof. Dilhan M. Kalyon, Ms. Asli Ergun, and Mr. Halil Gevgilili for their help with twin screw extrusion.

\section{References:}

[1] AMINI A R, LAURENCIN C T, NUKAVARAPU S P. Bone tissue engineering: recent advances and challenges. Crit. Rev. Biomed. Eng., 2012, 40(5): 363-408.

[2] DROSSE I, VOLKMER E, CAPANNA R, et al. Tissue engineering for bone defect healing: an update on a multi-component approach. Injury, 2008, 39(Suppl 2): S9-S20.

[3] ANDRIC T, SAMPSON A C, FREEMAN J W. Fabrication and characterization of electrospun osteon mimicking scaffolds for bone tissue engineering. Mater. Sci. Eng. C, 2011, 31: 2-8.

[4] ERGUN A, YU X, VALDEVIT A, et al. In vitro analysis and me- chanical properties of twin screw extruded single-layered and coextruded multilayered poly(caprolactone) scaffolds seeded with human fetal osteoblasts for bone tissue engineering. J. Biomed. Mater. Res. A, 2011, 99: 354-366.

[5] OZKAN S, KALYON D, YU X, et al. Multifunctional proteinencapsulated polycaprolactone scaffolds: fabrication and in vitro assessment for tissue engineering. Biomaterials, 2009, 30: 4336-4347.

[6] ERISKEN C, KALYON D, WANG H. Functionally graded electrospun polycaprolactone and beta-tricalcium phosphate nanocomposites for tissue engineering applications. Biomaterials, 2008, 29: $4065-4073$.

[7] MCCLURE M, SELL S, SIMPSON D, et al. A three-layered electrospun matrix to mimic native arterial architecture using polycaprolactone, elastin, and collagen: a preliminary study. Acta Biomater., 2010, 6: 2422-2433.

[8] BOHNER M, TADIER S N, VAN GARDEREN N, et al. Synthesis of spherical calcium phosphate particles for dental and orthopedic applications. Biomatter., 2013, 3(2): e25103.

[9] BOSE S, TARAFDER S. Calcium phosphate ceramic systems in growth factor and drug delivery for bone tissue engineering: a review. Acta Biomater., 2012, 8(4): 1401-1421.

[10] CHEN X Q, CHEN X N, ZHU X D, et al. Effect of surface topography of hydroxyapatite on human osteosarcoma MG-63 cell. Journal of Inorganic Materials, 2013, 28(8): 901-906.

[11] WANG J, CHEN Y, ZHU X, et al. Effect of phase composition on protein adsorption and osteoinduction of porous calcium phosphate ceramics in mice. J. Biomed. Mater. Res. A, 2014, 102(12): 4234-4243. 
[12] SAMAVEDI S, WHITTINGTON A R, GOLDSTEIN A S. Calcium phosphate ceramics in bone tissue engineering: a review of properties and their influence on cell behavior. Acta Biomater., 2013, 9(9): 8037-8045.

[13] ZHANG L, HANAGATA N, MAEDA M, et al. Porous hydroxyapatite and biphasic calcium phosphate ceramics promote ectopic osteoblast differentiation from mesenchymal stem cells. Sci. Technol. Adv. Mater., 2009, 10: 025003.

[14] ULERY B D, NAIR L S, LAURENCIN C T. Biomedical applications of biodegradable polymers. J. Polym. Sci. B Polym. Phys., 2011, 49(12): 832-864.

[15] CHEN X, ERGUN A, GEVGILILI H, et al. Shell-core bi-layered scaffolds for engineering of vascularized osteon-like structures. Biomaterials, 2013, 34: 8203-8212.

[16] GREGORY C, GUNN W, PEISTER A, et al. An Alizarin red-based assay of mineralization by adherent cells in culture: comparison with cetylpyridinium chloride extraction. Anal. Biochem., 2004, 329: $77-84$.

[17] YANG X, CHEN X, WANG H. Acceleration of osteogenic differentiation of preosteoblastic cells by chitosan containing nanofibrous scaffolds. Biomacromolecules, 2009, 10: 2772-2778.

[18] RAJZER I, MENASZEK E, KWIATKOWSKI R, et al. Electrospun gelatin/poly( $\varepsilon$-caprolactone) fibrous scaffold modified with calcium phosphate for bone tissue engineering. Mater. Sci. Eng. C, 2014, 44: 183-190.

[19] LE NIHOUANNEN D, SAFFARZADEH A, GAUTHIER O, et al. Bone tissue formation in sheep muscles induced by a biphasic calcium phosphate ceramic and fibrin glue composite. J. Mater. Sci. Mater. Med., 2008, 19: 667-675.

[20] MILLER J, STEVENS K, YANG M, et al. Rapid casting of patterned vascular networks for perfusable engineered three-dimensional tissues. Nat. Mater., 2012, 11: 768-774.

\title{
磷酸钲相组成对类骨单位复合骨支架的影响
}

\author{
陈雪宁 ${ }^{1}$, 范红松 ${ }^{1}$, 王红军 ${ }^{2}$
}

(1. 四川大学 国家生物医学材料工程技术研究中心, 成都 610064; 2. 斯蒂文斯理工学院 化学、生化和生物医学工程 学院, 美国新泽西 07030)

摘 要: 从组成上看, 自然骨是一种无机与有机的复合材料; 从结构上看, 致密骨的基本结构单位为内壁血管化的骨 单位。本研究基于组成与结构仿生的原理制备组织工程化支架, 模拟具有复杂结构的密质骨的基本单位一一骨单位。 为此, 通过静电纺丝和双螺杆挤出相结合的两步制造法, 制备一种具有双层结构的聚己内酯/磷酸钲( $\mathrm{PCL} / \mathrm{CaP})$ 复合骨 支架, 其内层是由电纺纳米纤维组成的空心管，可贴附内皮细胞层形成与哈佛氏管相类似的结构; 其外层是具有高孔 隙率的螺旋状 PCL/CaP 微丝, 可复合前成骨细胞以模拟骨单位结构中的外层骨样组织。为进一步探索材料组成对于 支架生物功能的影响, 分别设计了外层为 PCL, PCL/双相磷酸钙 $(\mathrm{PCL} / \mathrm{BCP})$ 和 PCL/ $/$-磷酸三钙 $(\mathrm{PCL} / \beta-\mathrm{TCP})$ 的复合支 架, 比较了材料组分变化对外层微丝结构及前成骨细胞(MC3T3-E1)活性的影响。相比于 PCL 和 PCL/ $\beta-\mathrm{TCP}$, PCL/BCP 微丝更能显著增强细胞的生长和钻的沉积, 并成功获得可精确调控不同细胞的空间分布的双层复合支架, 实现对复杂结构骨单位的模拟构建，显示出很好的应用前景。

关 键 词: 磷酸钙; 相组成; 复合材料; 骨单位; 双螺杆挤出

中图分类号: R318

文献标识码: A 